\title{
Anterior wall myocardial infarction in a 16- year-old man caused by coronary artery aneurysm during the outbreak of COVID-19
}

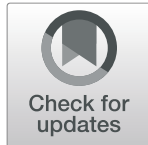

Wenshuai Ma, Chunyu Li, Wei Zhang, Zhaole Ji and Yan Li (iD

\begin{abstract}
Background: Coronary artery aneurysm (CAA) is a potential cause of infarction. During the outbreak of coronavirus disease 2019 (COVID-19), home isolation and activity reduction can lead to hypercoagulability. Here, we report a case of sudden acute myocardial infarction caused by large CAA during the home isolation.

Case presentation: During the outbreak of coronavirus disease 2019 (COVID-19),a 16-year-old man with no cardiac history was admitted to CCU of Tang du hospital because of severe chest pain for $8 \mathrm{~h}$. The patient reached the hospital its own, his electrocardiogram showed typical features of anterior wall infarction, echocardiography was performed and revealed local anterior wall dysfunction, but left ventricle ejection fraction was normal, initial high-sensitivity troponin level was $7.51 \mathrm{ng} / \mathrm{mL}(<1.0 \mathrm{ng} / \mathrm{mL})$. The patient received loading dose of aspirin and clopidogrel bisulfate and a total occlusion of the LAD was observed in the emergency coronary angiography (CAG). After repeated aspiration of the thrombus, TIMI blood flow reached level 3. Coronary artery aneurysm was visualized in the last angiography. No stent was implanted. Intravascular ultrasound (IVUS) was performed and the diagnosis of coronary artery aneurysm was further confirmed. The patient was discharged with a better health condition.
\end{abstract}

Conclusions: Coronary artery aneurysm is a potential reason of infarction, CAG and IVUS are valuable tools in diagnosis in such cases, during the outbreak of coronavirus disease 2019 (COVID-19), home isolation and activity reduction can lead to hypercoagulability, and activities at home should be increased in the high-risk patients.

Keywords: Acute myocardial infarction, Coronary artery aneurysm, IVUS

\section{Background}

Coronary artery aneurysm (CAA) is a potential reason of infarction. During the outbreak of coronavirus disease 2019 (COVID-19), home isolation and activity reduction can lead to hypercoagulability. Here, we report a case of large CAA complicated with acute myocardial infarction (AMI) in a 16-year-old man during the home isolation.

\footnotetext{
* Correspondence: profleeyan@163.com

Department of Cardiology, Tangdu Hospital, Air Force Medical University, Xi'an 710032, China
}

(c) The Author(s). 2020 Open Access This article is licensed under a Creative Commons Attribution 4.0 International License, which permits use, sharing, adaptation, distribution and reproduction in any medium or format, as long as you give appropriate credit to the original author(s) and the source, provide a link to the Creative Commons licence, and indicate if changes were made. The images or other third party material in this article are included in the article's Creative Commons licence, unless indicated otherwise in a credit line to the material. If material is not included in the article's Creative Commons licence and your intended use is not permitted by statutory regulation or exceeds the permitted use, you will need to obtain permission directly from the copyright holder. To view a copy of this licence, visit http://creativecommons.org/licenses/by/4.0/ The Creative Commons Public Domain Dedication waiver (http://creativecommons.org/publicdomain/zero/1.0/) applies to the data made available in this article, unless otherwise stated in a credit line to the data.

\section{Case presentation}

During the outbreak of coronavirus disease 2019 (COVID-19), a 16-year-old man with no cardiac history was admitted to CCU of Tang du hospital because of severe chest pain for $8 \mathrm{~h}$. the patient reached the hospital its own. His cardiovascular examination revealed an initial blood pressure of $110 / 65 \mathrm{mmHg}$, heart rate of 95b.p.m.,body mass index (BMI) $15.5 \mathrm{~kg} / \mathrm{m} 2$, his electrocardiogram showed typical features of anterior wall infarction (Fig. 1) with a raised initial high-sensitivity troponin level which was $7.51 \mathrm{ng} / \mathrm{mL}(<1.0 \mathrm{ng} / \mathrm{mL})$. On auscultation, his chest was clear and heart sounds were 


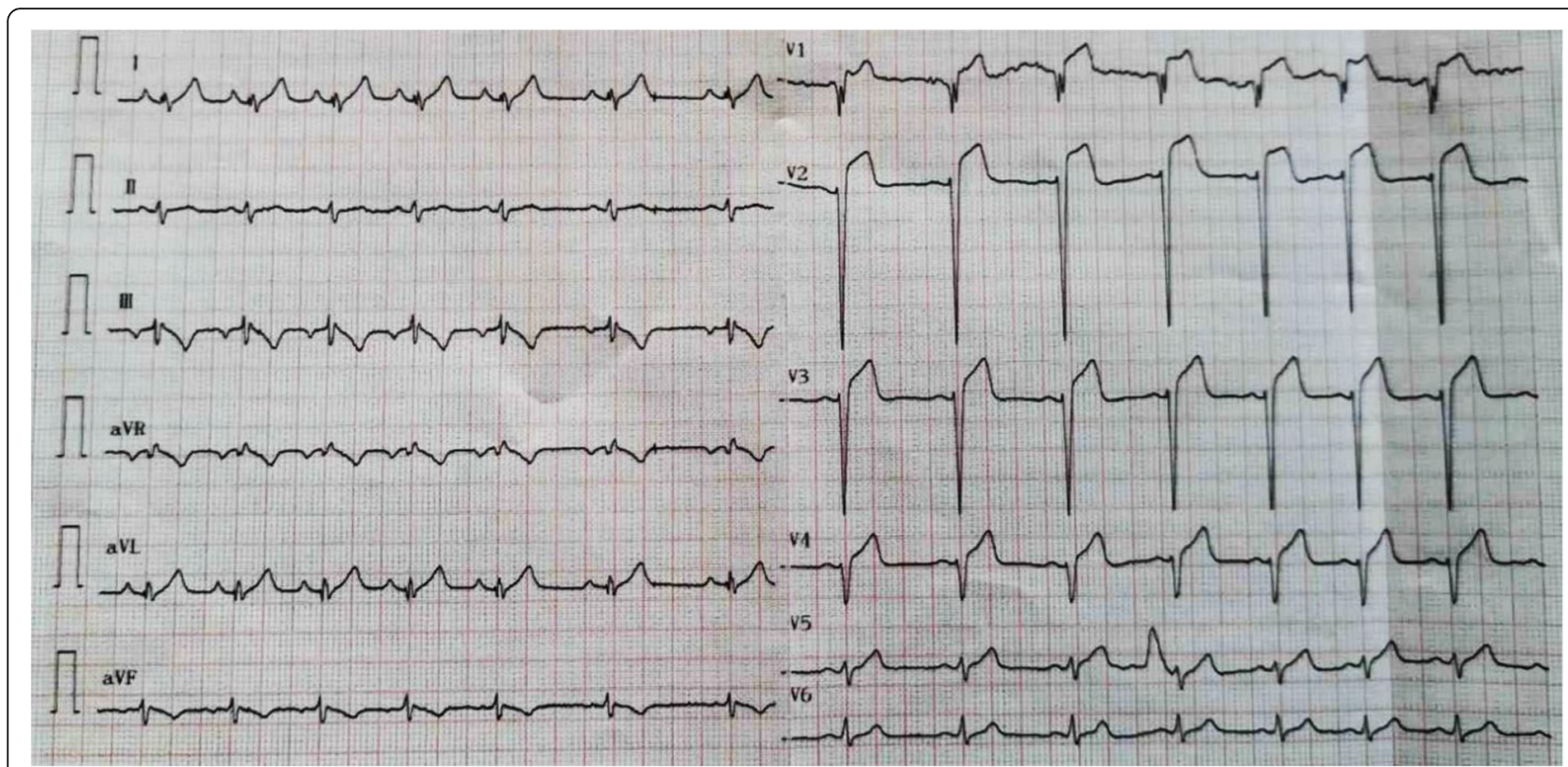

Fig. 1 Electrocardiogram showing sinus tachycardia with ST-segment elevation on V1-5

normal. In echocardiography, we found local anterior wall dysfunction, but left ventricle ejection fraction was normal (Fig. 2a, b). He had neither a history of hypertension, diabetes, smoking nor a family history of coronary heart disease. He had neither cold nor fever recently., and he denied the possibility of a past exposure to COVID-19. No medication was taken before admission. The patient received loading dose of aspirin and clopidogrel bisulfate, angiography that was performed immediately after transfer to the hospital, a total occlusion of the LAD from the proximal segment (Fig. 3a) was observed in the emergency coronary angiography (CAG). Right coronary artery and left circumflex artery were normal. A guidewire was successfully advanced across the occlusive lesion and a large fresh red thrombus was removed by aspiration catheter. After repeated aspiration of the thrombus and intra-coronary injection of tirofiban and urokinase, TIMI blood flow reached to level 3. Coronary artery aneurysm was visualized in the last angiography (Fig. 3b). Intravascular ultrasound (IVUS) was performed and further confirmed the diagnosis of coronary artery aneurysm (Fig. 4). No stent was implanted. ECG after the event showed resolution of MI pattern and evolution of infarction has been observed. After the emergency, results of laboratory assessments included normal levels of electrolytes, blood lipid and glucose, the C-reactive protein (CRP) level was $2.27 \mathrm{mg} / \mathrm{L}(0-3 \mathrm{mg} / \mathrm{L})$ and erythrocyte sedimentation rate (ESR) was $20 \mathrm{~mm} / \mathrm{h}$
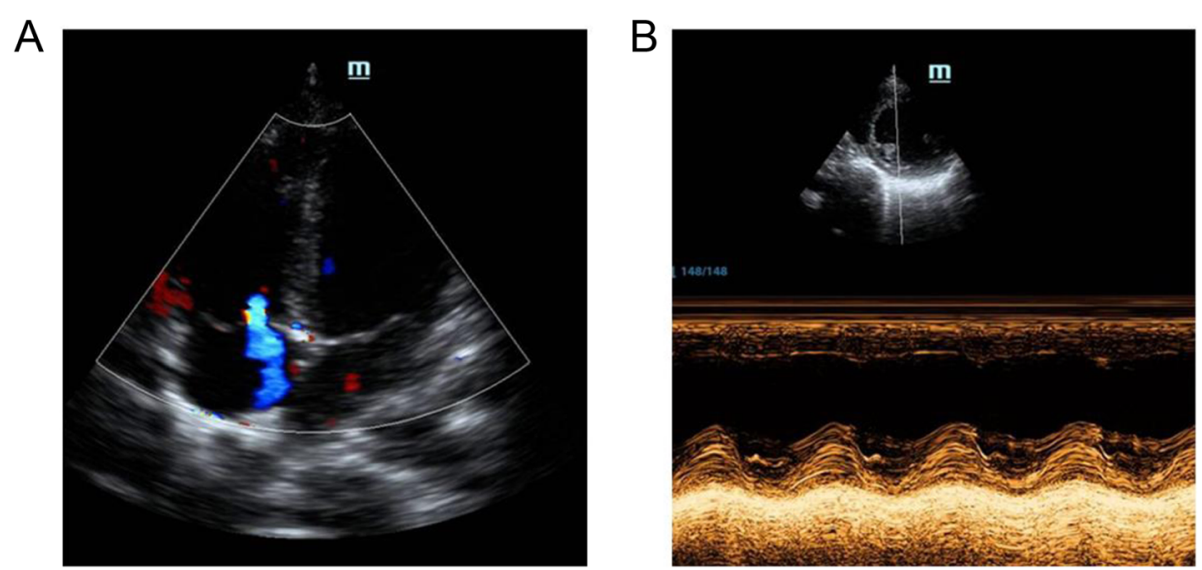

Fig. 2 a In transthoracic echocardiography, local anterior wall dysfunction has been observed. b M-mode echocardiography showed left ventricle ejection fraction was good 
A

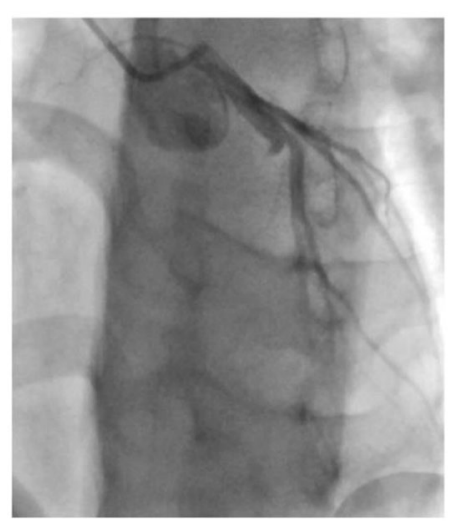

B

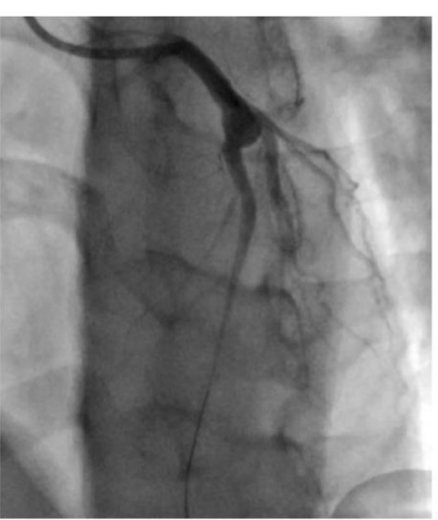

Fig. 3 a Left coronary angiogram revealed a total occlusion of the LAD from the proximal segment; $\mathbf{b}$ Left coronary angiogram revealed a very large round aneurysm (arrowheads) originating from the proximal segment of the LAD

$(0-15 \mathrm{~mm} / \mathrm{h})$, NT-proBNP was $670 \mathrm{pg} / \mathrm{ml}$, nucleic acid testing was negative, both inflammatory marker and rheumatoid factors were normal, ANA and other autoimmune markers were negative ruling out active connective tissue disease. The chest CT scan was normal. His test result for COVID-19 was negative. A computed tomography angiography (CTA) scan 5 days after admission showed that coronary artery aneurysm in the LAD (Fig. 5). the widest segment was about $8.6 \mathrm{~mm}$. The patient was discharged home $7 \mathrm{~d}$ later on dual anti-platelet therapy (aspirin $100 \mathrm{mg}$ and clopidogrel $75 \mathrm{mg}$ ).

\section{Discussion and conclusions}

Coronary artery aneurysm is a potential reason of infarction. In older adults, Coronary artery aneurysm is associated with coronary atherosclerosis in more than $50 \%$ of cases. Other causes include Kawasaki's disease (KD), Behcet's Syndrome; Polyarteritis nodosa, Takayasu's disease, Connective Tissue Disorders like Marfan syndrome, HIV, fungal, syphilitic Infections; use of illicit drugs like a mphetamine, cocaine [1] In our case, the patient is a 16-year-old man, in CAG, a total occlusion of the LAD was observed, but Right coronary artery and left circumflex artery were normal, and no atherosclerotic plaque was observed in IVUS. So the cause of infarction is not associated with atherosclerotic stenotic lesions. The patient and his parents denied the history of exposure to COVID19, and his test result for COVID-19 was normal. They denied the history of Kawasaki's disease, ANA and other autoimmune markers were negative ruling out active connective tissue disease, but maybe he had Kawasaki disease history when he was a child, but he and his parents did not know it.

The definition of coronary artery aneurysm is the internal diameter of coronary arteries dilatate $>1.5$ times larger than the adjacent angiographically normal artery [2]. the diagnostic methods include CAG, IVUS and CTA. the CAG is an important diagnostic method for the coronary artery aneurysm. IVUS can not only
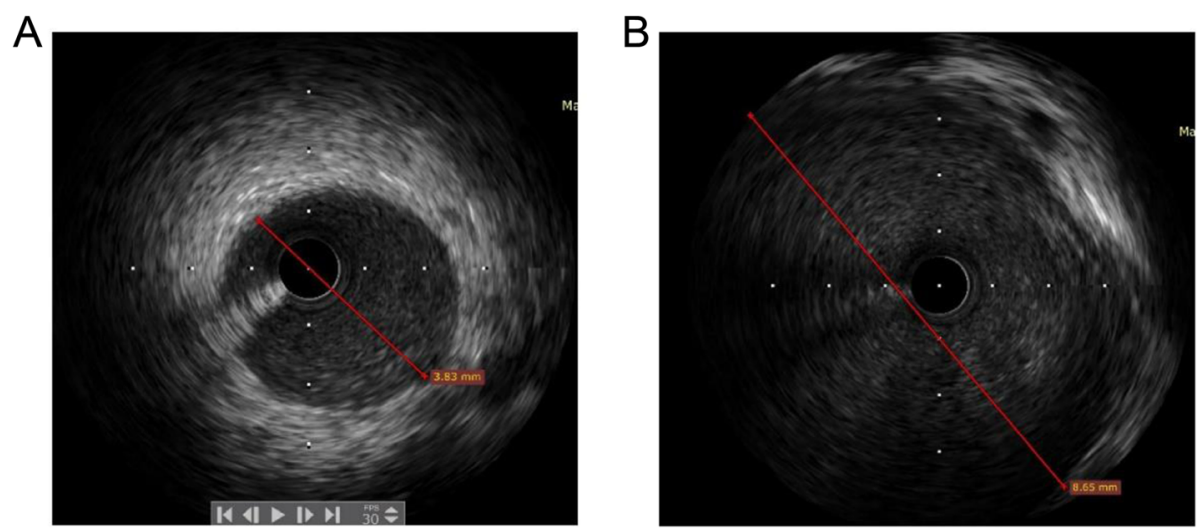

Fig. 4 a IVUS showing normal LAD, the vessel diameter was $3.8 \mathrm{~mm}$. b IVUS showing Coronary artery aneurysm, the widest segment was about $8.6 \mathrm{~mm}$ 


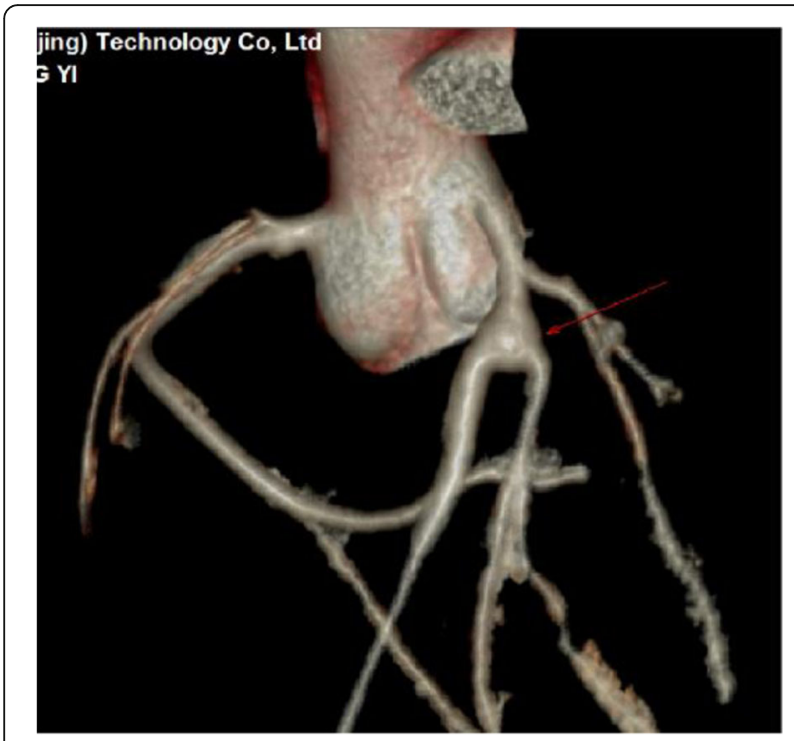

Fig. 5 CTA showing a very large round aneurysm originating from the proximal segment of the LAD (red arrow indicating the aneurysm)

accurately measure the diameter of aneurysm, but also distinguish between true aneurysm and pseudoaneurysm.

Coronary aneurysm was an obstructive ischemic coronary artery disease with impaired flow volume and may lead to exercise-induced myocardial ischemia [3]. The coronary flow reserve was also markedly reduced in the coronary aneurysms [4]. Computational fluid dynamics simulation has demonstrated that the hemodynamic parameters were different between coronary aneurysms and normal arteries specifically. The time-averaged wall shear stress (TAWSS) may be decreased and the oscillatory shear index (OSI) may be increased in aneurysms [5]. These changes could induce focal endothelial cell dysfunction and inflammation, which primes arterial regions for subsequent atherosclerosis initiation in response to hypercholesterolemia, and promote the transformation of stable plaque subtypes to unstable subtypes [6, 7]. And this hemodynamic changes in coronary aneurysms may increase blood viscosity and activates coagulation [8].

Coronary artery aneurysm is a potential cause of infarction. The treatments of CAA include medical, interventional and surgical therapy, because of there are no large clinical trials or guidelines in this subject., the treatment varies from doctor to doctor Medical treatments include antiplatelet agents, thrombolytic agents and anticoagulants [9]. In our case, we chose conservative management., dual anti-platelet therapy (aspirin $100 \mathrm{mg}$ and clopidogrel 75 $\mathrm{mg}$ ). The patient was in good condition during the 1month follow-up. During the outbreak of COVID-19, home isolation and activity reduction can lead to hypercoagulability, infarction is more likely to happen., so activities at home should be increased in the high-risk patients.

\section{Abbreviations}

COVID-19: Coronavirus disease 2019; CCU: Cardiac care unit;

IVUS: Intravascular ultrasound, CAG: Coronary angiography; LAD: Left anterior descending; ECG: Echocardiography; MI: Myocardial infarction; BMI: Body mass index; CRP : C-reactive protein; PCl: Percutaneous coronary intervention; ESR: Erythrocyte sedimentation rate; ANA: Antinuclear antibodies;

CTA: Computed tomography angiography; HIV: Human immunodeficiency virus; TAWSS: Time-averaged wall shear stress; OSI: Oscillatory shear index

\section{Acknowledgements}

Not applicable.

\section{Authors' contributions}

WSM drafted the manuscript. CYL made critical revision of the manuscript. $W Z$, YL, and WSM performed the percutaneous coronary interventions. ZLJ contributed to data and images collection, YL provided consultation, participated in the design and coordination of the manuscript. All authors read and approved the final manuscript.

Funding

Not applicable.

\section{Availability of data and materials}

All relevant data is contained within the manuscript.

Ethics approval and consent to participate Not applicable.

\section{Consent for publication}

Written informed consent for publication of the clinical details and images was obtained from the patient. A copy of the consent form is available for review by the Editor of this journal.

\section{Competing interests}

The authors declare that they have no competing interest.

Received: 21 April 2020 Accepted: 22 June 2020

Published online: 01 July 2020

\section{References}

1. Yach D, Stuckler D, Brownell KD. Epidemiologic and economic consequences of the global epidemics of obesity and diabetes. Nat Med. 2006;12:62-6.

2. Shridhar P, Smith T, Khalil R, Lasorda D, Chun Y. Exclusion of giant coronary artery aneurysm with covered stent combined with coil embolization of vessel outflow. Med Case Rep. 2016;2(3):1-3.

3. Krüger D, Al Mokhtari NE, Wieckhorst A, Rausche T, Simon-Herrmann $G$, Simon R. Evidence of pathological coronary flow patterns in patients with isolated coronary artery aneurysms. Coron Artery Dis. 2008;19:249-55.

4. Kruger D, EIMokhtari NE, Wieckhorst A, Simon-Herrmann G, Simon R. Intravascular ultrasound study and evidence of pathological coronary flow reserve in patients with isolated coronary artery aneurysms. Clin Res Cardiol. 2010;99:157-64.

5. Noelia GG, Mathew M, McCrindle BW, Tran JS, Kahn AM, Burns JC, Marsden AL. Hemodynamic variables in aneurysms are associated with thrombotic risk in children with Kawasaki disease. Int J Cardiol. 2019;22: $1515-26$.

6. Kwak BR, Back M, Bochaton-Piallat ML, Caligiuri G, Daemen MJ, Davies PF, Hoefer IE, Holvoet P, Jo H, Krams R, Lehoux S, Monaco C, Steffens S, Virmani R, Weber C, Wentzel JJ, Evans PC. Biomechanical factors in atherosclerosis: mechanisms and clinical implications. Eur Heart J. 2014;35:3013-20 3020a3020d.

7. Brown AJ, Teng Z, Evans PC, Gillard JH, Samady H, Bennett MR. Role of biomechanical forces in the natural history of coronary atherosclerosis. Nat Rev Cardiol. 2016;13:210-20.

8. Doi T, Kataoka Y, Noguchi T, Shibata T, Nakashima T, Kawakami S, Nakao K, Fujino M, Nagai T, Kanaya T, Tahara Y, Asaumi Y, Tsuda E, Nakai M, Nishimura K, Anzai T, Kusano K, Shimokawa H, Goto Y, Yasuda S. Coronary artery Ectasia predicts future cardiac events in 
patients with acute myocardial infarction. Arterioscler Thromb Vasc Biol. 2017;37:2350-5.

9. Befeler B, Aranda MJ, Embi A, Mullin FL, El-Sherif N, Lazzara R.

Coronary artery aneurysms: study of the etiology, clinical course and

effect on left ventricular function and prognosis. Am J Med. 1977;62:

597-607.

\section{Publisher's Note}

Springer Nature remains neutral with regard to jurisdictional claims in published maps and institutional affiliations.

Ready to submit your research? Choose BMC and benefit from:

- fast, convenient online submission

- thorough peer review by experienced researchers in your field

- rapid publication on acceptance

- support for research data, including large and complex data types

- gold Open Access which fosters wider collaboration and increased citations

- maximum visibility for your research: over $100 \mathrm{M}$ website views per year

At $\mathrm{BMC}$, research is always in progress.

Learn more biomedcentral.com/submissions 